\title{
The Impact of Corporate Governance on Banks Performance and Loan Quality: Evidence From Italian Cooperative Banks*
}

\author{
Candida Bussoli, Marisa Gigante, Maria Bruna Tritto \\ University LUM Jean Monnet, Casamassima (Bari), Italy
}

\begin{abstract}
In the banking system, a context characterized by growing instability and by the speed of evolution of business dynamics, the system of corporate governance plays a key role, both for large banks and for banks with a smaller size. The paper aims to investigate the influence of corporate governance of the banks that operate in the cooperative credit system on performance and quality of loans, over the years 2010-2011-2012. In order to achieve this aim, the following research hypotheses have been formulated: There is a statistically significant relationship between the size and the structure of the board and banks performance operating in the cooperative credit system; there is a statistically significant relationship between the size and structure of the board and the credit quality of banks operating in the cooperative credit system. The analysis is conducted on a sample composed of 48 Italian banks, divided into 24 cooperative banks and 24 popular banks. The sample is made up of banks from all over Italy and very different in terms of dimension. For the sample construction, data relative to governance of banks were collected from the balance sheets in the period from June to August 2014. Financial-economic data were collected from the Financial Statements and from Bankscope database. The methodology of analysis is based on multivariate OLS (ordinary least squares) regression models. The main results refer to the presence of significant relationships between board dimension and the quality of loans and among the number of committees and performance and the quality of loans. The presence of a significant and negative relationship between the board dimension and the ratio of impaired loans to gross loans indicates the possibility that enlargement of board dimension allows a better quality of loans. The presence of a positive relationship between the number of committees and the ratio of impaired loans to gross loans signals the possibility that a greater number of committees can produce a worse quality of loans. The presence of a negative relationship between the number of committees and bank performance suggests to limit and manage the complexity of governance in banks operating in the cooperative credit system.
\end{abstract}

Keywords: bank, cooperative credit system, corporate governance, loans quality, performance

\footnotetext{
* This paper is the result of a joint effort and a continuous exchange of ideas among the three authors. The individual parts are attributed as follows: Candida Bussoli has written "Introduction" and "Conclusion"; Marisa Gigante has written "The Impact of Corporate Governance on the Financial and Non-financial Companies Performance", "Research Results", and "Analysis"; and Maria Bruna Tritto has written "The Impact of Corporate Governance on Banks Performance" and "Research Methods".

Candida Bussoli, associate professor of financial markets and institutions at the University LUM Jean Monnet, Casamassima (Bari), Italy.

Marisa Gigante, Ph.D., assistant professor in financial markets and institutions at the University LUM Jean Monnet, Casamassima (Bari), Italy.

Maria Bruna Tritto, assistant professor in financial markets and institutions at the University LUM Jean Monnet, Casamassima (Bari), Italy.

Correspondence concerning this article should be addressed to Candida Bussoli, the University LUM Jean Monnet, SS $100 \mathrm{~km}$ 18, Casamassima (Bari) 70010, Italy. E-mail: bussoli@lum.it.
} 


\section{Introduction}

In the Italian banking system, cooperative credit system has become increasingly important; in spite of the dramatic recession, it has been particularly strong. This is mainly due to its structure, historically characterized by the prevalence of credit intermediation in favor of families and enterprises, by strong local roots, and by a balance-sheet structure which is broadly balanced. Cooperative banks and popular banks have small propensity to take risky choices, thanks to their proximity to customers/members and the effective understanding of their needs and creditworthiness. The mentioned aspects represent strong points for banks operating in the cooperative credit system, but these banks are also characterized by weak points, such as a limited number of options in raising capital and a complex governance model, exposed to unstable conditions, that can also affect negatively the performance and the efficiency of banks (Fonteyne, 2007; Mottura, 2011).

The literature on the relationship between corporate governance and performance has produced mixed results, often discordant, but feeds a growing debate, regarding the importance of corporate governance to achieve conditions of sound and prudent management and overall performance.

Literature has focused on the relationship between corporate governance and performance in the financial and non-financial companies (Yermack, 1996; Eisenberg, 1998; Carretta, 2011; Vafeas, 1999; Hermalin \& Weisbach, 2003) and on the impact of corporate governance on banks performance (Adams \& Mehran, 2003; Fields \& Keys, 2003; Belkhir, 2009; Adams \& Ferreira, 2009; Mayur \& Saravanan, 2006).

The paper aims to investigate the impact of the dimension and structure of the board that characterize institutions working in the field of cooperative credit, on the functions carried out by the board of directors, consequently, on bank performance, and on the quality of its credits.

The analysis is conducted on a sample composed of 48 Italian banks, divided into 24 cooperative banks and 24 popular banks. The sample consists of banks located throughout the country in order to represent the likely cooperative credit system in Italy.

The main results show a significant and negative relationship between board dimension and loans quality, a significant and positive relationship between the number of committees and the ratio of impaired loans to gross loans, and a negative relationship between the number of committees and performance. These results suggest to limit and manage the complexity of governance in banks operating in the cooperative credit system. Furthermore, these results highlight how committees, which can undoubtedly offer support and assistance to the board, make the governance structure more complex and this can adversely affect performance and credit quality.

The paper is composed as follows: Section 2 is devoted to a brief review of literature on the topic, in particular, which deals with the contributions focusing on the relationship between corporate governance and performance in financial and non-financial companies and in banks; section 3 shows the research methods in terms of methodology and sample; section 4 highlights main results from the analysis; and last section summarizes some brief conclusions.

\section{Literature Review}

The literature examined on the issue of governance is oriented towards two lines of development: (1) the relationship between corporate governance and performance in financial and non-financial companies and (2) the impact of corporate governance on banks performance. 


\section{The Impact of Corporate Governance on the Financial and Non-financial Companies Performance}

Considering the literature related to the relationship between corporate governance and companies performance, Jensen and Meckling (1976) focused on the relationship between top management and owners, whether shareholders or creditors of the organization. The authors concluded that decreasing the interest of ownership of managers, the incentive to maximize their business performance reduces and thus the value of the company. Therefore, good corporate governance could have a positive relationship with the corporate performance, when the property is dispersed.

With particular reference to the composition of the board, some scholars have attempted to assess the contribution of independent directors. Baysinger and Butler (1985) detected the presence of best performances in companies whose board includes a higher number of independent directors, unlike Yermack (1996) who, however, asserted the presence of negative relationship between the proportion of independent directors and company's performance.

As part of the works referred to the importance of board dimension, Jensen (1993) and Lipton and Lorsch (1992) have argued that higher board dimensions correspond to the overall reduced corporate performance. The reasons underlying this hypothesis are essentially attributable to the fact that when the board dimensions are too high, board's tasks become rather symbolic and dissociated from managerial processes.

Yermack (1996) tested the effect of board dimension on performance and management efficiency. The main hypothesis of this work is that board dimension represents an important determinant of the performance of companies and the results refer to the existence of an inverse relationship between the board dimension and enterprise value.

In support of this thesis, Eisenberg (1998) has identified a negative correlation between board dimension and company's performance, represented by Tobin's $Q$.

Hermalin and Weisbach (2003) confirmed these results, claiming that the consensus of the literature is geared to support the hypothesis that a wider board compromises the performance of the company.

In contrast to these results, other authors argued that the increased board dimension can be beneficial, as it can increase the skills and the resources available to the organization (Dalton, Daily, Johnson, \& Ellstrand, 1999).

In order to verify the impact of corporate governance on performance, many authors have focused on the organizational characteristics of the board, that is, on the presence of committees and on the frequency of meetings, as these factors can affect the quality of governance and corporate performance. Regarding the presence of committees, it seems to have a positive effect on corporate performance; this can be explained by referring to the complexity of tasks, whose growth requires the creation of organizational structures increasingly articulated.

In support of this evidence, Klein's theoretical contribution (1998) examined the effect arising from the existence of the committees on performance and indicated, as the latter is positively related to their presence and to that of independent directors who hold executive positions within them.

Regarding the frequency and operative methods of board meetings, Carretta (2011) stated that by increasing the frequency of the meetings, the possibility of control on the top management could grow.

The frequency of the meetings cannot be a synonym of the efficiency of the board of directors, if participation of directors is low, if the information system for the board is inadequate, and if their carrying out does not allow to achieve shared results. 
Vafeas (1999) argued that the frequency of meetings of the board is negatively related to performance, consequently, more frequent meetings of the board result in worse performance.

The issue of board diversity has been investigated only marginally and literature has come to different conclusions about the impact of the presence of female directors on performance.

Schwizer, Soana, and Cucinelli (2012) have studied the impact of board diversity on the number of meetings held by the board. Regarding the presence of independent women in the board, the results of the investigation point out a direct and significant relationship with the number of annual meetings held by the board. Therefore, the board of directors tends to meet more frequently, if they are composed of independent women.

\section{The Impact of Corporate Governance on Banks Performance}

On the second line of research that examines the impact of corporate governance on banks performance, literature leads to mixed results (Bussoli, 2012).

Considering board dimension, Adams and Mehran (2003) noted that the banking companies have wider boards than industrial firms, due to the complex organizational structure and, subsequently, they examined the relationship between the board dimension of banks and their performance, approximated by a measure of Tobin's $Q$. In contrast to the evidence noted for non-financial companies, they showed a positive relationship between the board dimension and Tobin's $Q$ measure.

Belkhir (2009) has led to a positive relationship between board dimension and performance in a sample of banks and financial companies.

The analysis shows that this relationship may depend on the positive effects of an expansion of banks board dimension in response to the increase in size of the same, as an external growth resulting from M\&A (Mergers \& Acquisitions) operations.

Finally, several authors have found, in contrast to the literature, that board dimension has no effect on banks performance. More precisely, Mayur and Saravanan (2006) analyzed the impact of corporate governance on banks performance, measured by Tobin's $Q$ and by the market to book ratio.

The results of the work have shown the absence of a dependency relationship between bank performance and board dimension. These results are interesting as made in a context in which the system of corporate governance is evolving.

A further aspect refers to the board composition, in particular the impact of the presence of female directors on the boards of the banks. According to Adams and Ferreira (2009), the boards of directors are more effective, when they can have a larger number of talented individuals and, in particular, women have a different approach than men, they have greater ease in managing relationships, having diversified personal profiles (Fields \& Keys, 2003).

However, according to Eisenberg (1998), increasing of gender differentiation could lead to the reduction of harmony within the "team" of directors, since it can affect the confidence among members of different genders and their willingness to cooperate.

This would result in the need to replace the whole trust with alternative mechanisms of coordination of behaviors and decisions, with an increase of organizational costs.

Sufficient empirical evidence still lack, however, it can be argued that the evolution of the board role requires, especially in banks, in the light of the renewed framework of the system of internal and external controls, a greater diversity of skills and behavior of its members in any case. For this reason, a greater 
presence of women in the board could quickly lead to a general improvement in the overall quality of the organization and of functioning of the board.

The reference literature, especially internationally, is wide, but it comes to mixed results and feeds a growing debate regarding the importance of governance to achieve conditions of sound and prudent management and overall performance (Bussoli, 2013).

Therefore, the present work aims to investigate, in the cooperative credit system, the influence of board dimension and board structure on performance and credit quality.

In order to achieve this aim, the following research hypotheses have been formulated:

H1: There is a statistically significant relationship between the size and the structure of the board and banks performance operating in the cooperative credit system;

$\mathrm{H} 2$ : There is a statistically significant relationship between the size and structure of the board and the credit quality of banks operating in the cooperative credit system.

\section{Research Methods}

\section{Methodology}

In order to test the research hypotheses, multivariate OLS (ordinary least squares) regression models have been used.

The first and second models allow to verify the first research hypothesis: The dependent variable is represented by performance measures, such as Roaa and Roae. The third model allows to verify the second research hypothesis: The dependent variable is the ratio of impaired loans to gross loans:

$$
\begin{aligned}
& \operatorname{Roaa}_{i}=\beta_{0}+\beta_{1} \operatorname{Lbdim}_{i}+\beta_{2} \operatorname{Wom}_{i}+\beta_{3} \operatorname{Lcn}_{i}+\beta_{4} \operatorname{Tcr}_{i}+\beta_{5} \operatorname{Ldim}_{i}+\beta_{6} \mathrm{Gtl}_{i}+\varepsilon_{i} \\
& \operatorname{Roae}_{i}=\beta_{0}+\beta_{1} \operatorname{Lbdim}_{i}+\beta_{2} \operatorname{Wom}_{i}+\beta_{3} \operatorname{Lcn}_{i}+\beta_{4} \operatorname{Tcr}_{i}+\beta_{5} \operatorname{Ldim}_{i}+\beta_{6} \mathrm{Gtl}_{i}+\varepsilon_{i} \\
& \operatorname{Credet}_{i}=\beta_{0}+\beta_{1} \operatorname{Lbdim}_{i}+\beta_{2} \operatorname{Wom}_{i}+\beta_{3} \operatorname{Lcn}_{i}+\beta_{4} \mathrm{Tcr}_{i}+\beta_{5} \operatorname{Ldim}_{i}+\beta_{6} \mathrm{Gtl}_{i}+\varepsilon_{i}
\end{aligned}
$$

The dependent variables considered for the years 2010, 2011, and 2012 are as follows:

- Roaa $i$ : return on average assets. It expresses the efficiency with which the bank uses its assets to generate income and it is calculated as the ratio between net income and the average value of total assets in the financial year; data were collected from the database Bankscope;

- Roae $i$ : return on average equity. It is the rate of return on equity, calculated as the ratio between net income and average value of the equity in the financial year; data were collected from the database Bankscope;

- Credet $t_{i}$ : credit. It indicates the quality of the loans of the bank and is calculated as the ratio of impaired loans to gross loans; data were collected from the database Bankscope.

The examined independent variables for the years 2009, 2010, and 2011 are as follows:

- $\operatorname{Lbdim}_{i}$ : board dimension. It is expressed in natural logarithm of the number of board members; data were collected from the balance sheet and websites of banks;

- $\mathrm{Wom}_{i}$ : wom. It represents the percentage of the female directors, measured by the ratio between the number of women in the board and the total number of board members; data were collected from the balance sheet and websites of banks;

- $\mathrm{Lcn}_{i}$ : $\mathrm{lcn}$. It indicates the number of committees set up in the banks expressed in natural logarithm and extrapolated from the data of balance sheet;

The control variables examined for the years 2009, 2010, and 2011 are as follows:

- $\operatorname{Ldim}_{i}:$ bank size. It is measured by the natural logarithm of total assets, based on the data of balance sheet; 
- Tcri: total capital ratio. It indicates the capital adequacy ratio according to Basel rules, as provided by the database Bankscope;

- $\mathrm{Gtl}_{i}$ : growth of gross loans. It is extracted from the database Bankscope.

The dependent variables are related to the years 2010-2011-2012, while the independent variables refer to the years 2009-2010-2011; so, the analysis explores the existence of a statistically significant relationship between dependent variables whose measures are subsequent to the measures of independent and control variables, in order to reduce potential endogeneity problems.

\section{Sample}

The analysis has been conducted on a sample of 48 Italian banks, divided into 24 cooperative banks and 24 popular banks, distributed evenly throughout the country and considered in the three years 2010-2011-2012. In particular, the sample is composed of an equal number of cooperative banks and popular banks, in order to represent likely the cooperative credit system in Italy. The analysis refers to the years 2010, 2011, and 2012, but for the construction of delayed variables, the series also includes the year 2009. For the sample construction, data relative to governance of banks were collected from the balance sheets and websites in the period from June to August 2014. Financial-economic data were collected from the "Financial Statements" and from "Bankscope" database.

\section{Research Results and Analysis}

The results of the empirical analysis are illustrated, taking into account the results of the regression models. Regarding the verification of the research hypotheses, the analysis was conducted by performing multivariate OLS regressions in periods 2010-2011-2012.

The OLS models are supported by the results of the analysis of collinearity and heteroskedasticity.

The result of collinearity tests allows to exclude problems of collinearity among the variables. The White test allows to exclude problems of heteroskedasticity. However, in all years under observation, robust standard errors analyses were carried out for a better quality of the results.

Table 1 shows the results of the analysis related to 2010, taking into account the Roaa dependent variable. The analysis was repeated for the Roae performance index (Table 2).

The models do not have a statistical significance. The results underline the influence of both the number of committees within the banks and the board dimension on Roae.

In particular, a greater number of committees lead to a deterioration of bank performance, while widening the board dimension, there is an improvement of the return on equity.

From this study, it can be argued that the first research hypothesis is not verified for both Roaa and Roae dependent variables in 2010. Considering the Credet dependent variable, the model referred to the year 2010 presents a significant $p$-value and a value of $R$-square equal to 0.269 (Table 3). The governance variable with a greater impact on credit quality is the number of committees ( $\mathrm{Lcn}$ ), while a lower incidence is found for the total capital ratio (Tcr), expression of the capital adequacy ratio. Therefore, for the year 2010, it can be stated that the second research hypothesis is verified for the Credet dependent variable. In 2011, the regression models relating to performance measures are statistically significant and the value of $R$-square is good, as the studied independent variables explain respectively $48.2 \%$ of the Roaa dependent variance (Table 4 ) and $53.8 \%$ of the Roae dependent variance (Table 5). 
Table 1

OLS Model-Regression-Roaa (2010)

\begin{tabular}{lccl}
\hline Roaa & & & \\
\hline Indip. Var. & Std. coeff. & $t$-statistic & $P$-value \\
\hline Cost & -1.2341 & -1.564 & 0.128 \\
Lbdim & 0.2526 & 0.911 & 0.369 \\
Wom & -0.3543 & -0.481 & 0.633 \\
Lcn & -0.1411 & -1.344 & 0.189 \\
Tcr & -0.0080 & -0.656 & 0.517 \\
Ldim & 0.0847 & 0.132 & 0.266 \\
Gtl & 0.0003 & 0.155 & 0.877 \\
\hline$R^{2}$ & 0.168313 & & \\
$F(6.29)$ & 0.876970 & $P$-value $(F)$ & 0.523840 \\
White test & 31.945976 & $P$-value $\left(x^{2}\right)$ & 0.234091 \\
\hline
\end{tabular}

Table 2

OLS Model-Regression-Roae (2010)

\begin{tabular}{lccc}
\hline Roae & & & \\
\hline Indip. Var. & Std. coeff. & $t$-statistic & $P$-value \\
\hline Cost & $13.9459^{* *}$ & -2.229 & 0.033 \\
Lbdim & $3.9069^{*}$ & 2.039 & 0.050 \\
Wom & -6.4124 & -1.080 & 0.289 \\
Lcn & $-1.4872^{*}$ & -1.917 & 0.065 \\
Tcr & 0.1198 & -1.407 & 0.170 \\
Ldim & 0.7832 & 1.456 & 0.156 \\
Gt1 & 0.1560 & 0.401 & 0.691 \\
\hline $\mathrm{R}^{2}$ & 0.260029 & & \\
$F(6.29)$ & 1.906262 & $P$-value $(F)$ & 0.113590 \\
White test & 27.066838 & $P$-value $\left(x^{2}\right)$ & 0.460193 \\
\hline
\end{tabular}

Notes. $*$ is $10 \%$ at level of significance and $* *$ is $5 \%$ at level of significance.

Table 3

OLS Model-Regression-Credet (2010)

\begin{tabular}{lccl}
\hline Credet & & & \\
\hline Indip. Var. & Std. coeff. & $t$-statistic & $P$-value \\
\hline Cost & $27.0500^{* * *}$ & 4.191 & 0.000 \\
Lbdim & -4.1164 & -1.369 & 0.181 \\
Wom & 8.5264 & 0.878 & 0.387 \\
Lcn & $2.5433^{* *}$ & 2.363 & 0.025 \\
Tcr & $0.1384^{*}$ & 1.716 & 0.096 \\
Ldim & -0.9802 & -1.651 & 0.109 \\
Gtl & 0.0016 & 0.088 & 0.930 \\
\hline$R^{2}$ & 0.269307 & & \\
$F(6.29)$ & 2.138764 & $P$-value $(F)$ & 0.078985 \\
White test & 27.437718 & $P$-value $\left(x^{2}\right)$ & 0.440381 \\
\hline
\end{tabular}

Notes. $*$ is $10 \%$ at level of significance; $* *$ is $5 \%$ at level of significance; and $* * *$ is $1 \%$ at level of significance.

These indices present a negative and significant relationship only with the total capital ratio, explaining how the increase in the capital adequacy ratio causes a reduction of the cooperative banks performance. 
From the obtained results, it can be asserted that the first research hypothesis is not verified for both Roaa and Roae dependent variables, for the year 2011.

Table 4

OLS Model-Regression-Roae (2011)

\begin{tabular}{lccl}
\hline Roaa & & & \\
\hline Indip. Var. & Std. coeff. & $t$-statistic & $P$-value \\
\hline Cost & 0.6193 & 0.794 & 0.432 \\
Lbdim & -0.0121 & -0.046 & 0.963 \\
Wom & 0.6884 & 1.299 & 0.201 \\
Lcn & -0.1224 & -1.084 & 0.285 \\
Tcr & $-0.0275^{* * *}$ & -3.703 & 0.000 \\
Ldim & 0.0134 & 0.194 & 0.846 \\
Gtl & 0.0005 & 0.874 & 0.387 \\
\hline$R^{2}$ & 0.482693 & & \\
$F(6.38)$ & 4.501180 & $P$-value $(F)$ & 0.001548 \\
White test & 23.460089 & $P$-value $\left(x^{2}\right)$ & 0.660066 \\
\hline
\end{tabular}

Notes. $*$ is $10 \%$ at level of significance; $* *$ is $5 \%$ at level of significance; and $* * *$ is $1 \%$ at level of significance.

Table 5

OLS Model-Regression-Roaa (2011)

\begin{tabular}{lccc}
\hline Roae & & & \\
\hline Indip. Var. & Std. coeff. & $t$-statistic & $P$-value \\
\hline Cost & 6.7690 & 0.790 & 0.434 \\
Lbdim & 0.4734 & 0.228 & 0.820 \\
Wom & 5.0731 & 1.038 & 0.306 \\
Lcn & -1.4559 & -1.155 & 0.255 \\
Tcr & $-0.3327^{* *}$ & -5.202 & 0.000 \\
Ldim & 0.0895 & 0.123 & 0.902 \\
Gtl & 0.0059 & 0.803 & 0.426 \\
\hline$R^{2}$ & 0.538361 & & \\
$F(6.38)$ & 6.410482 & $P$-value $(F)$ & 0.000100 \\
White test & 27.178956 & $P$-value $\left(x^{2}\right)$ & 0.454172 \\
\hline
\end{tabular}

Notes. $*$ is $10 \%$ at level of significance; $* *$ is $5 \%$ at level of significance; and $* * *$ is $1 \%$ at level of significance.

Table 6 shows the results of the regression analysis conducted for the dependent variable, relative to the quality of the loans (Credet), highlighting the goodness of the model $\left(R^{2}=0.30\right)$ and a significant $p$-value. The analysis illustrates that loans quality is influenced mainly by the number of committees set up in each bank (Lcn), as well as by bank size (Ldim) and the capital adequacy ratio (Tcr). The relationship between loans quality and the number of committees is positive, thus increasing the number of committees implies the increasing of impaired loans to gross loans.

In smaller banks, as cooperative banks and small popular banks, where there is not complexity of the tasks, the presence of a greater number of committees can make the banking activity more difficult because of the greater complexity of the structure of governance, and it may be counterproductive if it is not commensurate to the effective management complexity. The relationship between loan quality and bank size, measured by the natural logarithm of total assets, is negative, then a variation of the latter generates an improvement of loan 
quality. The results suggest that, in the context of cooperative credit, greater banks may show greater capacity of assessment and selection of loans. Finally, a positive relationship with the total capital ratio implies that an increase in capital adequacy ratio generates a deterioration in loan quality.

For the year 2011, these results show that the second research hypothesis is verified for the Credet dependent variable.

Table 6

OLS Model-Regression-Credet (2011)

\begin{tabular}{lccl}
\hline Credet & & & \\
\hline Indip. Var. & Std. coeff. & $t$-statistic & $P$-value \\
\hline Cost & $29.6139^{* * *}$ & 4.608 & 0.000 \\
Lbdim & -3.4367 & -1.423 & 0.162 \\
Wom & -4.2163 & -0.745 & 0.460 \\
Lcn & $2.9328^{* * *}$ & 3.375 & 0.001 \\
Tcr & $0.0863^{*}$ & 2.005 & 0.052 \\
Ldim & $-1.0918^{* *}$ & -2.411 & 0.020 \\
Gtl & -0.0063 & 1.503 & 0.141 \\
\hline$R^{2}$ & 0.305714 & & \\
$F(6.38)$ & 6.287991 & $P$-value $(F)$ & 0.000118 \\
White test & 21.580966 & $P$-value $\left(x^{2}\right)$ & 0.758354 \\
\hline
\end{tabular}

Notes. $*$ is $10 \%$ at level of significance; $* *$ is $5 \%$ at level of significance; and $* * *$ is $1 \%$ at level of significance.

The analysis of regression models observed in 2012 outlines a good value of $R$ square for both models, relating to Roaa and Roae dependent variables, as the independent variables explain respectively $36.9 \%$ of the Roaa dependent variance and $33.6 \%$ of the Roae dependent variance (Tables 7 and 8). Both models have a significant $p$-value. In 2012, the variable that has a greater impact on the performance variables is the size of the bank, which is expressed by the natural logarithm of total assets. The results underline a negative and significant relationship with the two indices Roae and Roaa. For both models, the relationship between the performance indices and the governance variable, relative to the number of committees set up in the banks, is negative; therefore, the presence of greater number of committees in a cooperative or popular bank reduces the bank performance.

Table 7

OLS Model-Regression-Roaa (2012)

\begin{tabular}{lccl}
\hline Roaa & & & \\
\hline Indip. Var. & Std. coeff. & $t$-statistic & $P$-value \\
\hline Cost & 1.6300 & 1.306 & 0.199 \\
Lbdim & 0.4368 & 1.104 & 0.276 \\
Wom & 0.9520 & 1.607 & 0.116 \\
Lcn & $-0.2930^{*}$ & -1.829 & 0.075 \\
Tcr & 0.0094 & 0.526 & 0.601 \\
Ldim & $-0.1762 * * *$ & -2.737 & 0.009 \\
Gtl & -0.0004 & -0.539 & 0.592 \\
\hline$R^{2}$ & 0.369636 & & \\
$F(6.37)$ & 54.58492 & $P$-value $(F)$ & 0.0000 \\
White test & 30.61010 & $P$-value $\left(x^{2}\right)$ & 0.2874 \\
\hline
\end{tabular}

Notes. $*$ is $10 \%$ at level of significance; $* *$ is $5 \%$ at level of significance; and $* * *$ is $1 \%$ at level of significance. 
Table 8

OLS Model-Regression-Roae (2012)

\begin{tabular}{lccc}
\hline Roae & & & \\
\hline Indip. Var. & Std. coeff. & $t$-statistic & $P$-value \\
\hline Cost & 24.3986 & 1.304 & 0.200 \\
Lbdim & 4.1206 & 0.715 & 0.478 \\
Wom & 4.7875 & 0.658 & 0.514 \\
Lcn & $-4.6945^{*}$ & -2.010 & 0.051 \\
Tcr & 0.0468 & 0.221 & 0.825 \\
Ldim & $-2.1458^{* *}$ & -2.335 & 0.025 \\
Gtl & 0.0063 & -0.422 & 0.675 \\
\hline$R^{2}$ & 0.336964 & & \\
$F(6.37)$ & 34.92840 & $P$-value $(F)$ & 0.0000 \\
White test & 35.24207 & $P$-value $\left(x^{2}\right)$ & 0.1328 \\
\hline
\end{tabular}

Notes. $*$ is $10 \%$ at level of significance; $* *$ is $5 \%$ at level of significance; and $* * *$ is $1 \%$ at level of significance.

Considering the analysis conducted on loans quality for the year 2012 (Table 9), it is possible to note that the dependent variable (Credet), measured by the ratio of impaired loans to gross loans, is influenced by the number of committees and the board dimension. As regards the number of committees, the relation with the dependent variable is positive, that is, increasing it, the loan quality worsens.

As it has already been noted in the regression model referring to the years 2010-2011, in smaller banks there is not complexity of the tasks and the presence of a greater number of committees can make more difficult the banking activity. The relationship between loan quality and board dimension is negative and significant, thus increasing the number of directors in the board allows to improve the credit quality.

As argued in the literature, a large board can make the management of the bank more efficient and effective, as the skills and resources available to the organization increase.

However, a large number of board members may cause a deterioration of decision-making and a lack of responsibility of the directors.

The analysis conducted with the regression model relative to loans quality of the examined banks suggests that the second research hypothesis is verified in the year 2012 .

Table 9

OLS Model-Regression-Credet (2012)

\begin{tabular}{lccl}
\hline Credet & & & \\
\hline Indip. Var. & Std. coeff. & $t$-statistic & $P$-value \\
\hline Cost & $43.0375^{* * *}$ & 2.724 & 0.010 \\
Lbdim & $-6.8712^{*}$ & -1.854 & 0.072 \\
Wom & 2.4209 & 0.369 & 0.714 \\
Lcn & $3.0130^{* * *}$ & 2.742 & 0.009 \\
Tcr & -0.0348 & -0.218 & 0.828 \\
Ldim & -1.1625 & -1.346 & 0.187 \\
Gtl & 0.0107 & 1.300 & 0.201 \\
\hline$R^{2}$ & 0.199860 & & \\
$F(6.35)$ & 1.870347 & $P$-value $(F)$ & 0.113843 \\
White test & 33.790538 & $P$-value $\left(x^{2}\right)$ & 0.172221 \\
\hline
\end{tabular}

Notes. $*$ is $10 \%$ at level of significance; $* *$ is $5 \%$ at level of significance; and $* * *$ is $1 \%$ at level of significance. 


\section{Conclusions}

The results of the paper highlight how the governance of popular banks and cooperative banks influences the performance and quality of loans.

Two research hypotheses were formulated: The first hypothesis refers to the existence of a statistically significant relationship between the dimension and structure of the board and banks performance; the second hypothesis refers to the possible existence of a statistically significant relationship between the dimension and structure of the board and the quality of the loans.

The results of this work confirm the research hypotheses but not in all years under observation.

The existence of a significant relationship between governance variables and performance variables is observable only for the Roae dependent variable in 2010. Instead, for the year 2012, both performance variables have a significant relationship with the number of committees set up in banks considered in the sample.

The result highlights that the high number of committees within a credit cooperative bank or a popular bank can have negative effects on business management and its performance. In smaller and local banks, with lower complexity of tasks, the presence of a greater number of committees (therefore a more complex board) can make less efficient the development of banking activity.

The conducted analysis also reveals that the second research hypothesis is verified for the year 2011. The quality of loans is affected by the Lcn governance variable: The increase in the number of committees could be associated with the deterioration of the quality of loans. For the year 2012, the second research hypothesis is verified, too: The ratio of impaired loans to gross loans is influenced by both board dimension and the number of committees.

The relationship between credit quality and the board dimension is negative: A larger board could lead to a beneficial impact on the quality of the loans. The result is in line with part of the literature which argues that larger boards can make the management of the bank more efficient and effective, as the skills and the resources available to the organization increase (Dalton et al., 1999; Belkhir, 2009; Adams \& Mehran, 2003).

\section{References}

Adams, R. B., \& Ferreira, D. (2009). Women in the boardroom and their impact on governance and performance. Journal of Financial Economics, 94, 291-309.

Adams, R. B., \& Mehran, H. (2003). Is corporate governance different for bank holding companies? Economic Policy Review, 9 , 123-142.

Baysinger, B. D., \& Butler, H. (1985). Corporate governance and the board of directors: Performance effects of changes in board composition. Journal of Law, Economics, and Organization, 1, 101-124.

Belkhir, M. (2009). Board of directors' size and performance in the banking industry. International Journal of Managerial Finance, 5(2), 201-221.

Bussoli, C. (2012). Corporate governance and bank performance in Italy. In A. Carretta and G. Mattarocci (Eds.), Financial systems in troubled waters. Information, strategies, and governance to enhance performances in risky times. London: Routledge.

Bussoli, C. (2013). Bcc nella crisi: Governance delle banche locali ed effetti sulla performance e sulla qualità del credito. Bancaria, 6, 28-41.

Carretta, A. (2011). Il credito cooperativo. Storia, diritto, economia, organizzazione. Bologna: Il Mulino.

Dalton, D. R., Daily, C. M., Johnson, J. L., \& Ellstrand, A. E. (1999). Number of directors and financial performance: A meta-analysis. Academy of Management Journal, 42, 674-686.

Eisenberg, T. (1998). Larger board size and decreasing firm value in small firms. Journal of Financial Economics, 48 , 35-54. 
Fields, M. A., \& Keys, P. Y. (2003). The emergence of corporate governance from wall St. to main St.: Outside directors, board diversity, earnings management, and managerial incentives to bear risk. The Financial Review, 38(1), 1-24.

Fonteyne, W. (2007). Cooperative banks in Europe (Policy issues, IMF working papers, Social Science Research, pp. 1-68).

Hermalin, B. E., \& Weisbach, M. S. (2003). Boards of directors as an endogenously determined institution: A survey of the economic literature. Federal Reserve Bank of New York Economic Policy Review, 9, 7-26.

Jensen, M. C. (1993). The modern industrial revolution, exit, and the failure of internal control systems. Journal of Finance, 48(3), 831-880.

Jensen, M., \& Meckling, W. (1976). Theory of the firm: Managerial behavior, agency costs and ownership structure. Journal of Financial Economics, 3(4), 305-360.

Klein, A. (1998). Firm performance and board committee structure. Journal of Law and Economics, 41(1), 275-303.

Lipton, M., \& Lorsch, J. (1992). A modest proposal for improved corporate governance. Business Lawyer, 48(1), 59-77.

Mayur, M., \& Saravanan, P. (2006). Does the board size really matter? An empirical investigation on the Indian banking sector. Journal of Corporate Governance, 5(2), 1-17.

Mottura, P. (2011). Banche cooperative e crisi finanziaria. Forme istituzionali da valorizzare con modelli di governance appropriati. Bancaria, 12, 15-28.

Schwizer, P., Soana, M. G., \& Cucinelli, D. (2012). I vantaggi della board diversity: Un'analisi empirica sul mercato italiano. Bancaria, 3, 24-36.

Vafeas, N. (1999). Board meeting frequency and firm performance. Journal of Financial Economics, 53(1), 113-142.

Yermack, D. (1996). Higher market valuation of companies with a small board of directors. Journal of Financial Economics, 40, $185-211$ 